\title{
SOIL QUALITY EVALUATION IN RANGELAND SOILS IN RELATION TO HEAVY METALS POLLUTION
}

\author{
Avaliação da Qualidade de Faixas de Solos Relacionadas à \\ Contaminação por Metais Pesados
}

E. U. Onweremadu ${ }^{1}$

I. C. Okoli ${ }^{2}$

O. O. Emenalom ${ }^{2}$

M. N. Opara ${ }^{2}$

E. T. Eshett ${ }^{1}$

\section{Abstract}

Heightened anthropogenic activities at the study site necessitated this investigation on soil quality. A transect soil survey technique was used to link sampled points from an open dumpsite towards the river valley. Three minipedons were dug and sampled per location and collected samples were used for various laboratory analyses. Results showed that soils of the dumpsite (OB1) had the highest soil quality morphological index (SQMI) value of 3.82, indicating best quality while the least SQMI was found in the ranch (SQMI = 1.27). The SQMI had significant correlations with OM (organic matter) $(r=0.82 ; p=0.001 ; n=72)$, clay $(r=65 ; p=0.01$; $\mathrm{n}=72), \mathrm{pH}(\mathrm{r}=0.58 ; \mathrm{p}=0.01 ; \mathrm{n}=72)$ and bulk density $(\mathrm{r}=0.71 ; \mathrm{p}=0.05 ; \mathrm{p}=0.05 ; \mathrm{n}=72)$. Although there were positive correlations between SQMI and copper and cadmium, heavy metals were poor predictors of SQMI, indicating that soil quality evaluation by SQMI assesses mainly soil physical fertility.

Keywords: Land; Soil; Bioaccumulation; Biotoxicity; Soil quality; Morphological index.

Department of Soil Science and Technology, Federal University of Technology, PMB 1526, Owerri, Nigeria

Department of Animal Science and Technology, Federal University of Technology, PMB 1526 Owerri, Nigeria. All correspondences to: E. U. Onweremadu; E-mail: uzomaonweremadu@yahoo.com 


\section{Resumo}

O aumento das atividades antropogênicas, no local de estudo, culminou com a necessidade de investigar a qualidade do solo. A técnica de transecto (corte no solo) foi utilizada para ligar pontos amostrais de um depósito de lixo a céu aberto até o vale de um rio. Três pequenas áreas foram demarcadas, escavadas e delas foram coletadas amostras para análises laboratoriais. Os resultados mostraram que o solo do depósito de lixo $\left(\mathrm{OB}_{1}\right)$ tinha melhor índice morfológico de qualidade do solo (SQMI = 3,82) que os valores encontrados num outro local determinado (SQMI = 1,27). O SQMI teve uma correlação significativa com OM (material orgânico) $(r=0,82 ; p=0,001 ; n=72)$, com a argila $(r=65 ; p=0,01 ; n=72)$, com o pH $(r=0,58 ; p=0,01$; $\mathrm{n}=72)$ e com a densidade $(r=0,71 ; \mathrm{p}=0,05 ; \mathrm{p}=0,05 ; \mathrm{n}=72)$. Embora exista correlação entre o SQMI, o cobre e o cádmio, metais pesados foram fracos indicadores deste parâmetro, mostrando que a avaliação da qualidade do solo por SQMI resulta principalmente em apontar para a fertilidade do solo.

Palavras-chave: Terra; Solo; Bioacumulação; Biotoxicidade; Qualidade do solo; Índice morfológico.

\section{Introduction}

The quality of soils determines their capacity to function well for any intended use. The current popularity of soil quality concept reflects the growing awareness that soil is an important component of the earth biosphere especially in the production of food and fibre (1). Soil quality decline implies degradation of soil resource which is the temporary or permanent lowering of the productive capacity of soil caused by overgrazing, deforestation, inappropriate agricultural practices, overexploitation of fuel wood leading to desertification and other problems (2). Oldeman et al. (3) reported that 35\% of Africa soils are lightly degraded, while $65 \%$ are extremely degraded. Intensive use of soil without equivalent inputs results in decline in agro-ecosystems through soil erosion and loss of soil microbes (4). This situation is heightened because of the diminution of organic matter and consequent degradation of soil properties (5). In addition to long and intensive cultivation without appropriate inputs, over-grazing impoverishes soil properties $(6,7)$.

Waste disposal activities of man have also resulted to soil quality decline. Wastes, especially solid wastes contain diverse materials many of which have toxic and hazardous constituents (8). Leachates from these hazardous wastes may include heavy metals that enter the soil system. In some circumstances, the heavy metals are transported to surface and ground waters (9). Heavy metals inputs have been found in site soils where wastes were used as soil amendments (10). Pasture and crop plants act as vehicles for transferring these heavy metals and other toxic constituents in the soil into the food chain. However, the mobility of metals from solid to solution in the soils is mainly controlled by sorption-desorption, chelation, precipitationdissolution, and oxidation-reduction processes of the metals in soils (11). Plants absorb heavy metals from the soil as well as from aerial deposits on leaves, fruits and stems (12). Some plants accumulate these toxic metals in their aboveground tissues where they constitute serious health and environmental problems not only because of the toxicity to crop plants but also because of the potentially dangerous health effects to man and grazing animals (13).

Thus, soil quality decline is an aftermath of anthropogenic activities. Earlier, Zinck (14) attributed degradation of soils to increased human population and consequent pressure on soils for many conflicting uses. Evaluation of soils to ascertain their health status is therefore necessary. Soil quality evaluation exercise generates land information necessary for promoting food security (15) by implementing agricultural development programmes (16). Andrews et al. (17) remarked that soil quality concept depends on inherent capabilities, intended uses and management goals. Soil survey is specifically a relevant tool for generating soil and soil-related data for improved understanding of landscape processes $(18,19)$. Information from soil survey report helps in modeling soil, vegetation, hydrology and grazing activities of animals (20). Hanson et al. (21) noted that detailed inventories on agroecosystem and processes enhance sustainable rangelands. It is often argued that spatial heterogeneity in soil quality exists as a result of differential use of areas by grazing animals $(22 ; 23)$ that integrated croplivestock systems improve sustainable use of soils (24). Evaluation studies such as this will go a 
length in improving the predictability of such scientific assertions. Currently, there are a wide variety of crop and livestock models but substantial work remains in combining these into robust systems models that can account for the major interactions within crop-livestock system (25).

Based on the foregoing and on the fact that there is a causal nexus between land, population, poverty and degradation especially in an excruciating humid tropical agroenvironment, it becomes necessary to investigate rangelands for the purpose of accumulating useful soil and soil-related data for their sustainable management.

The major aim of this study was to investigate soil quality of rangeland soils of a peri-urban community of Obinze in Imo state southeastern Nigeria by using a numerical soil quality index.

\section{Materials and Methods}

\section{Site selection and characterization}

Obinze is a military settlement lying between latitudes $5^{\circ} 10^{\prime}$ and $5^{\circ} 25^{\prime}$ North and longitudes $6^{\circ} 45^{\prime}$ and $7^{\circ} 00^{\prime}$ East. Obinze is a periurban community at a distance of about 25 kilometres away from the metropolitan city of Owerri, southeastern Nigeria. Although, it is a military settlement, the site is a home for nomads especially from northern part of the country who settle around the barracks with their herds of animals especially cattle. These animals are grazed on surrounding rangelands. Consequently, the vegetation of the rangelands tend to be more of derived savanna than rainforest as a continuous grazing. The major geological material of the site is Coastal Plain Sands (Benin formation) of the Oligocene-Miocene era (26). Obinze is a lowland area (27). It is a humid tropical environment. The average annual rainfall is about $2400 \mathrm{~mm}$ with 3 months of dryness. Temperatures are high and change only slightly during the year $\left(27-29^{\circ} \mathrm{C}\right)$. Crop farming is mainly practiced at subsistence level with traditional slash and burn system. Mixed cropping is prominent and soil fertility regeneration is by bush fallow. Cassava-maize mixtures are common while plantains and bananas are planted at waste dumpsites and abandoned pit latrines.

\section{Field studies}

A transect was established from an open waste dump site, 100 metres away from the Army Barracks in Obinze towards the Otamiri River in Imo state. Beginning from the dumpsite to the last sampled location was a distance of 350 metres. In all, 8 sampled points were established as $\mathrm{OB}_{1}, \mathrm{OB}_{2}, \mathrm{OB}_{3}, \mathrm{OB}_{4}, \mathrm{OB}_{5}, \mathrm{OB}_{6}, \mathrm{OB}_{7}$ and $\mathrm{OB}_{8}$ and are described in Table 1. 
TABLE 1: Description of sampled sites

\begin{tabular}{|c|c|c|c|}
\hline Location & $\begin{array}{l}\text { Distance } \\
\text { Barracks (m) }\end{array}$ & $\begin{array}{l}\text { Human } \\
\text { Influence }\end{array}$ & Vegetation \\
\hline $\mathrm{OB}_{1}$ & 100 & Open dump site & $\begin{array}{l}\text { Luxuriant grasses (Panicum } \\
\text { maximum etc) Caloprogonium } \\
\text { mucunoides and relics woody } \\
\text { shrubs. }\end{array}$ \\
\hline $\mathrm{OB}_{2}$ & 150 & End of dumpsite & $\begin{array}{l}\text { Grasses (Panicum } \\
\text { maximum,Sida acuta, Imperata } \\
\text { cyclindrica and Acioa barteri }\end{array}$ \\
\hline $\mathrm{OB}_{3}$ & 200 & Ranch & $\begin{array}{l}\text { Very few grasses (Panicum } \\
\text { maximum, Axonopus } \\
\text { compressus). }\end{array}$ \\
\hline $\mathrm{OB}_{4}$ & 250 & Weedy arable farm & $\begin{array}{l}\text { Cassava-dominated plus grasses } \\
\text { (Panicu,m maximum, Axonopus } \\
\text { compressus and pteridophytes. }\end{array}$ \\
\hline $\mathrm{OB}_{5}$ & 300 & Open field(1) & $\begin{array}{l}\text { Imperata-dominated plus } \\
\text { Panicum maximum }\end{array}$ \\
\hline $\mathrm{OB}_{6}$ & 350 & Open field(2) & $\begin{array}{l}\text { Sparsely grassed with Imperata } \\
\text { and Panicum interspersed with } \\
\text { woody shrubs }\end{array}$ \\
\hline $\mathrm{OB}_{7}$ & 400 & Military range(1) & $\begin{array}{l}\text { Suppressed grasses (Panicum } \\
\text { maximum, Axonopus } \\
\text { compressus) }\end{array}$ \\
\hline $\mathrm{OB}_{8}$ & 450 & Military range(2) & Shrub-dominated grassy vegetatio \\
\hline
\end{tabular}

Sampling was done at an equidistance of 50 metres. Three minipedons were dug in each sampling location giving a total of 24 minipedons for the study. Each minipedon had 3 layers at predetermined depths of $0-10 \mathrm{~cm}$, $10-20 \mathrm{~cm}$ and $20-30 \mathrm{~cm}$ and this is necessary for soil quality evaluation using soil quality morphological index (SQMI) as recommended by Seybold et al. (28). They stated that SQMI is used to assess near-surface soil attributes quantitatively for the estimation of soil quality. These depths are necessary in the computation of SQMI as they represent SRI 0-10, SRI 10-20 and SRI 20-30 where SRI is the structure-rupture resistance. Soil samples were collected from the bottommost layer upwards to avoid contamination and a total of 72 soil samples were collected. 


\section{TABLE 2: Texture-weighting class criteria for SQMI}

\begin{tabular}{|l|l|}
\hline Texture class & Criteria \\
\hline A & Sand, loamy sand \\
\hline B & Not A and clay is $<18 \%$ \\
\hline C & $18-40 \%$ clay \\
\hline D & $\geq 40 \%$ clay \\
\hline
\end{tabular}

SQMI = soil quality morphological index.

Table 3: Criteria for placement of structure class in the SQMI

\begin{tabular}{|l|l|}
\hline $\begin{array}{l}\text { Structure } \\
\text { class }\end{array}$ & Criteria \\
\hline 1 & $\begin{array}{l}\text { All structures with common or many stress surfaces irrespective of } \\
\text { other features, massive, platy with firm or stronger horizontal } \\
\text { rupture resistance, all weak structure except granular, moderate } \\
\text { very coarse prismatic, all columnar. }\end{array}$ \\
\hline 2 & $\begin{array}{l}\text { All structures with few stress surfaces irrespective of other features, } \\
\text { weak, granular, moderate very coarse and coarse blocky, coarse } \\
\text { and medium prismatic, platy with friable horizontal rupture } \\
\text { resistance, strong very coarse and coarse prismatic. }\end{array}$ \\
\hline 3 & $\begin{array}{l}\text { No stress surfaces; moderate medium blocky; very fine, fine medium } \\
\text { prismatic; platy with very friable horizontal rupture resistance; strong } \\
\text { very coarse and coarse blocky. }\end{array}$ \\
\hline 4 & $\begin{array}{l}\text { No stress surfaces, moderate granular, moderate very fine and fine } \\
\text { blocky; strong fine. }\end{array}$ \\
\hline 5 & $\begin{array}{l}\text { No stress surfaces, strong granular, strong very fine through medium } \\
\text { blocky and very fine prismatic. }\end{array}$ \\
\hline
\end{tabular}

The texture weighting class, structure class and rupture resistance class for each layer was described (29). Texture weighting class was based on the percentage of clay. Soil structure was determined by type, grade and size of structural units. The higher the SQMI the better and SQMI value lies between 0 and 100 (29). Ruptureresistance class was estimated by combining texture-weighting class and moist rupture-resistance (Table 2, 3, 4). 


\section{TABLE 4: Rupture resistance classes for the SQMI}

\begin{tabular}{|l|c|c|c|c|c|}
\hline $\begin{array}{l}\text { Texture } \\
\text { class }\end{array}$ & Loose & $\begin{array}{l}\text { Very } \\
\text { friable }\end{array}$ & Friable & Firm & $\begin{array}{l}\text { Very firm } \\
\text { \& stronger }\end{array}$ \\
\hline A & 2 & 3 & 3 & 2 & 1 \\
\hline B & 3 & 4 & 3 & 2 & 1 \\
\hline C & 4 & 5 & 3 & 2 & 1 \\
\hline D & 5 & 5 & 4 & 1 & 1 \\
\hline
\end{tabular}

Leaves of Panicum maximum growing on the soils were used for the study. The leaves were harvested at their succulent stage of development in all the sampled points. The leaf samples were oven-dried at $80^{\circ} \mathrm{C}$ for 24 hours after washing and later ground with the aid of a blender. Coning and quartering technique was used to obtain sub-samples of dried plant materials for analysis. The ground samples were placed in clean glass bottles and ovendried again at a temperature of $65^{\circ} \mathrm{C}$ for 24 hours in readiness for heavy metals analysis.

\section{Laboratory analyses}

Soil particle size distribution was determined by hydrometer method according to the procedure of Gee and Bauder (30). Bulk density was determined by the method of Blake and Hartge (31). Exchangeable basic cations and total exchangeable acidity were measured according to the method described by Thomas (32) and these exchangeable cations (calcium, magnesium, potassium, sodium, aluminium and hydrogen) were summed to give effective cation exchange capacity (ECEC). Base saturation (Bsat) was calculated as total exchangeable bases (TEB) divided by ECEC multiplied by $100 \%$. Aluminium saturation (Alsat) was similarly computed as exchangeable aluminium divided by ECEC multiplied by $100 \%$. Soil pH was estimated electrometrically using the procedure of Hendershot et al. (33). Total carbon was obtained by wet oxidation method (34). Spectrophotometric analyses of soil samples were carried out after preextraction of cations with dithionite-citrate carbonate according to the procedure of Hesser (35) as follows: Two and half grams of each soil sample was weighed into a beaker and the same quantity of sodium dithionite was added. This was prepared by adding $88.23 \mathrm{~g}$ of sodium citrate to $21.02 \mathrm{~g}$ of citric acid in a two-litre flask and made to mark with distilled water to give exactly $0.15 \mathrm{M}$ sodium citrate and $0.05 \mathrm{M}$ citric acid essential for this extraction. The beaker was shaken overnight in a shaking machine and later filtered with Whatman no. 42 filter paper. Twenty-five milliliters of the extract were pipetted into a $200 \mathrm{ml}$ beaker and $5 \mathrm{ml}$ of $30 \% \mathrm{H}_{2} \mathrm{O}_{2}$ was added after which the beaker was covered with watch glass. The sample was allowed to cool. Then, $10 \mathrm{ml}$ of $\mathrm{HNO}_{3}-\mathrm{H}_{2} \mathrm{SO}_{4}$ acid mixture was added in a fume chamber with the sample again digested for 3 hours 30 minutes until the extract became clear. The extract was allowed to cool and diluted with distilled water and made to $100 \mathrm{ml}$ in a volumetric flask. Concentrations of Nickel, Vanadium, Copper and Cadmium in the extract were determined using Perkin Elmer Model 2280/2380 Atomic Absorption Spectrophotometer. Readings were taken at 316.30 $\mu \mathrm{m}$ for Nickel, $228.90 \mu \mathrm{m}$ for Vanadium, $422.7 \mu \mathrm{m}$ for Copper Cadmium.

For the plant material, $1 \mathrm{~g}$ was weighted into $50 \mathrm{ml}$ beakers, followed by the addition of 10 $\mathrm{ml}$ of $6 \mathrm{M} \mathrm{HCl}$ (analytical grade). The beakers containing the samples for different sampled points were covered and heated for 15 minutes, followed by the additions of $1 \mathrm{ml} \mathrm{HNO}_{3}$. The digestion was performed at $95^{\circ} \mathrm{C}$ until about $4 \mathrm{ml}$ was left in the beaker. Then, a further $1 \mathrm{ml}$ of $6 \mathrm{M} \mathrm{HCl}$ was added, swirled and $10 \mathrm{ml}$ of water added. The beakers with their contents were heated again on the steam bath to complete dissolution. On cooling, the solution was filtered through a Whatman no. 541 filter paper into a $50 \mathrm{ml}$ volumetric flask and made 
to mark with water (36). Mineralization blanks were carried out using the same procedure but without plant materials. Thereafter, concentrations of heavy metals in the extracts were analyzed using Perkin Elmer Moder 2280/2380 Atomic Absorption Spectrophotometer and readings recorded.

\section{Statistical analyses}

Coefficient of variation, correlation and computer-based step-wise regression analyses were performed on the soil and plant data according to the procedure of Little et al. (37).

\section{Results and discussion}

\section{Soil quality}

Results of SQMI are shown in Table 5 with soils of the open dumpsite $\left(\mathrm{OB}_{1}\right)$ having the best quality (SQMI=3.82), followed by arable farm $\left(\mathrm{OB}_{4}\right)$ $(\mathrm{SQMI}=3.06)$ and least quality value recorded in the ranch $\left(\mathrm{OB}_{3}\right)(\mathrm{SQMI}=1.27)$.

TABLE 5: Mean values of sqmi. Variability and variability rating

\begin{tabular}{|l|l|l|l|l|}
\hline Location & SQMI & SD & CV(5) & Rating \\
\hline $\mathrm{OB}_{1}$ & 3.82 & 0.50 & 13 & Slight variation \\
$\mathrm{OB}_{2}$ & 2.63 & 0.80 & 30 & Moderate variation \\
$\mathrm{OB}_{3}$ & 1.27 & 0.12 & 9 & Slight variation \\
$\mathrm{OB}_{4}$ & 3.06 & 0.70 & 22 & Moderate variation \\
$\mathrm{OB}_{5}$ & 1.39 & 0.20 & 14 & Slight variation \\
$\mathrm{OB}_{6}$ & 1.42 & 0.15 & 10 & Slight variation \\
$\mathrm{OB}_{7}$ & 1.58 & 0.19 & 12 & Slight variation \\
$\mathrm{OB}_{8}$ & 2.72 & 0.62 & 22 & Moderate variation \\
\hline
\end{tabular}

SQMI = soil quality morphological index, $\mathrm{SD}=$ standard deviation,

$\mathrm{CV}=$ coefficient of variation. ${ }^{*}$ Rating was according to Aweto (38).

Slight variations in soil quality were encountered in $\mathrm{OB}_{1}, \mathrm{OB}_{3}, \mathrm{OB}_{5}, \mathrm{OB}_{6}$ and $\mathrm{OB}_{7}$. High SQMI values of the open dumpsite could be attributed to high organic matter content and consequent improvement of the physical properties of soil especially soil structure. The soil organic matter content is a major contributing factor in aggregation and aggregate stability of soils with low exchangeable sodium percentage (39). In soil quality evaluation by SQMI, soil structure is a major variable evaluated because it facilitates soil properties such as infiltration, porosity, moisture availability to plants and susceptibility to soil erosion (40). The least SQMI value recorded in
$\mathrm{OB}_{3}(\mathrm{SQMI}=1.27)$ is indicative of total breakdown of unstable soil aggregates resulting in the collapse of soil pores and consequent production of finer particles and microaggregates resulting in seal formation.

Soil properties

Soil properties studied are shown in Table 6. Soils were sandy, extremely to strongly acidic and of low effective cation exchange capacity (ECEC). Bulk density values were high except in the dumpsite. Base saturation was low $(<50 \%)$ except in soils of the dumpsite having 58\%. Conversely aluminium saturation (Alsat) was high 
except in soils of the dumpsite (Alsat $=32 \%$ ). Organic matter content of the site was generally low although high in soils of the dumpsite (4.21\%). These soil properties influenced SQMI values as in Table 5. Naturally soils are sandy being derived from Coastal Plain Sands and this condition interacted with the excruciating humid climate to set in motion pedogenic processes of leaching, elluviation, illuviation and rapid mineralization of organic matter. Grazing and cultivation activities may have contributed to decline in organic matter and increase in bulk density of soils. A bulk density of $1.64 \mathrm{Mgm}^{-3}$ ) obtained in the ranch can be explained by the stocking density of cattle.

TABLE 6: Mean values of selected soil properties in the study site

\begin{tabular}{|cccccccccc|}
\hline Loc. & $\begin{array}{l}\text { Sand } \\
\%\end{array}$ & $\begin{array}{l}\text { Silt } \\
\%\end{array}$ & $\begin{array}{l}\text { Clay } \\
\%\end{array}$ & $\begin{array}{l}\text { BD } \\
\left(\mathbf{M g m}^{-3}\right)\end{array}$ & $\begin{array}{l}\text { ECEC } \\
(\mathbf{c m o l k g})\end{array}$ & $\begin{array}{l}\text { Bsat } \\
\%\end{array}$ & $\begin{array}{l}\text { Alsat } \\
\%\end{array}$ & $\begin{array}{l}\mathbf{p H} \\
(\mathbf{K C 1})\end{array}$ & $\begin{array}{l}\text { OM } \\
\%\end{array}$ \\
\hline $\mathrm{OB}_{1}$ & 82 & 4 & 14 & 1.28 & 9.12 & 58 & 32 & 5.3 & 4.21 \\
\hline $\mathrm{OB}_{2}$ & 86 & 6 & 8 & 1.32 & 6.35 & 48 & 42 & 5.0 & 3.06 \\
\hline $\mathrm{OB}_{3}$ & 86 & 8 & 6 & 1.64 & 2.68 & 26 & 65 & 3.5 & 2.92 \\
\hline $\mathrm{OB}_{4}$ & 88 & 8 & 4 & 1.54 & 6.63 & 49 & 46 & 5.1 & 2.26 \\
\hline $\mathrm{OB}_{5}$ & 75 & 2 & 3 & 1.58 & 4.32 & 36 & 62 & 3.8 & 1.94 \\
\hline $\mathrm{OB}_{6}$ & 94 & 2 & 4 & 1.56 & 4.36 & 37 & 61 & 3.8 & 1.96 \\
\hline $\mathrm{OB}_{7}$ & 88 & 2 & 10 & 1.62 & 3.24 & 30 & 64 & 4.0 & 1.88 \\
\hline $\mathrm{OB}_{8}$ & 86 & 3 & 11 & 1.61 & 3.26 & 34 & 62 & 4.1 & 2.02 \\
\hline
\end{tabular}

$\mathrm{BD}=$ Bulk density, ECEC = effective cation exchange capacity, Bsat $=$ base saturation, Alsat $=$ aluminium saturation, $\mathrm{OM}=$ organic matter.

Table 7 shows the distribution of heavy metals in soils of the site. Nickel values ranged from $7.8 \pm 80.62 \mathrm{mgkg}^{-1}$ to $24.38 \pm 6.00 \mathrm{mgkg}^{-1}$. Others were distributed as follows: Vanadium $(0.16 \pm 0.01-$ $\left.2.06 \pm 0.4 \mathrm{mgkg}^{-1}\right)$, Cadmium (0.1+0.01-5.2+1.00 mgkg $\left.{ }^{1}\right)$ and copper $\left(28.24 \pm 4.1-76.21 \pm 5.71 \mathrm{mgkg}^{-1}\right)$. 
TABLE 7: Distribution of heavy metals in soils of study site (mean \pm sd)

\begin{tabular}{|l|l|l|l|l|}
\hline Location & Nickel & Vanadium & Copper & Cadmium \\
\hline $\mathrm{OB}_{1}$ & $24.38 \pm 6.00$ & $2.06 \pm 0.04$ & $76.21 \pm 5.71$ & $5.2 \pm 1.00$ \\
$\mathrm{OB}_{2}$ & $21.22 \pm 5.31$ & $1.18 \pm 0.01$ & $44.05 \pm 6.64$ & $3.1 \pm 1.00$ \\
$\mathrm{OB}_{3}$ & $15.14 \pm 6.12$ & $0.90 \pm 0.01$ & $32.55 \pm 5.16$ & $2.6 \pm 1.00$ \\
$\mathrm{OB}_{4}$ & $12.33 \pm 2.01$ & $0.20 \pm 0.01$ & $28.24 \pm 4.11$ & $0.5 \pm 0.08$ \\
$\mathrm{OB}_{5}$ & $8.26 \pm 1.22$ & $0.22 \pm 0.01$ & $33.29 \pm 6.10$ & $0.3 \pm 0.02$ \\
$\mathrm{OB}_{6}$ & $9.14 \pm 2.61$ & $0.16 \pm 0.01$ & $34.46 \pm 7.12$ & $0.3 \pm 0.01$ \\
$\mathrm{OB}_{7}$ & $10.30 \pm 1.84$ & $0.21 \pm 0.01$ & $35.28 \pm 5.14$ & $0.1 \pm 0.01$ \\
$\mathrm{OB}_{8}$ & $7.88 \pm 0.62$ & $0.18 \pm 0.01$ & $38.33 \pm 4.13$ & $0.2 \pm 0.01$ \\
\hline
\end{tabular}

The results showed that the open dump site with the best soil quality (SQMI=3.82) had the highest concentration of heavy metals in the study site. This tends to prove that SQMI is a little subjective and measures physical and not chemical fertility and quality of soils. Again, the presence of these heavy metals in all the sampled points confirms that heavy metals are naturally occurring in soils) (41). The values nickel, copper, vanadium and cadmium were $12.8 \pm 3.2,5.2 \pm 0.4,<.0 .2$ and $<0.2 \mathrm{mgkg}^{-1}$ respectively in the Obiobi/Obirikom communities of Rivers state Nigeria (42). The variability in the surface concentrations of these metals could be related to source of heavy metal, hydrodogical and lithological properties of soils of respective sites. Except in minipedons located on and around the open dump site, others had heavy metal concentrations below the critical level recommended by FEPA (43). In the leaves of P. maximum, heavy metals distribution was as follows: Nickel $\left(0.002 \pm 0.001-0.018 \pm 0.003 \mathrm{mgkg}^{-1}\right)$, copper $\left(1.22+0.2-6.32 \pm 0.2 \mathrm{mgkg}^{-1}\right)$ and cadmium $\left(0.1+0.01-0.9 \pm 0.03 \mathrm{mgkg}^{-1}\right)$ as indicated in Table 8 . Soil properties influence soil quality hence may have affected uptake of heavy metals by Panicum maximum. In a similar study, Lee (44) reported that cadmium uptake by rice was influenced by soil properties particularly clay and soil $\mathrm{pH}$. However high levels of these metals in the soil may produce high concentrations in P. maximum (45). Nonetheless bioavailability and uptake of heavy metals by plants may relate to the age and part of the plant. Wang and Liao (46) reported that uptake of heavy metals increases as plant grows, then falls as the crop reaches maturity. 
TABLE 8: Distribution of heavy metals in leaves of Panicum maximum (mean $\pm s d)$

\begin{tabular}{|l|l|l|l|l|}
\hline \multicolumn{5}{|c|}{ Heavy metals (mgkg $)$} \\
\hline Location & Nickel & Vanadium & Copper & Cadmium \\
\hline $\mathrm{OB}_{1}$ & $0.018 \pm 0.003$ & $0.088 \pm 0.003$ & $6.32 \pm 0.2$ & $0.9 \pm 0.03$ \\
$\mathrm{OB}_{2}$ & $0.012 \pm 0.003$ & $0.042 \pm 0.01$ & $4.16 \pm 0.3$ & $0.6 \pm 0.04$ \\
$\mathrm{OB}_{3}$ & $0.009 \pm 0.003$ & $0.033 \pm 0.02$ & $3.42 \pm 0.1$ & $0.6 \pm 0.03$ \\
$\mathrm{OB}_{4}$ & $0.006 \pm 0.002$ & $0.028 \pm 0.02$ & $2.42 \pm 0.2$ & $0.4+0.01$ \\
$\mathrm{OB}_{5}$ & $0.003 \pm 0.001$ & $0.026 \pm 0.01$ & $2.46 \pm 0.2$ & $0.4 \pm 0.01$ \\
$\mathrm{OB}_{6}$ & $0.003 \pm 0.002$ & $0.021 \pm 0.01$ & $1.38 \pm 0.1$ & $0.1 \pm 0.01$ \\
$\mathrm{OB}_{7}$ & $0.002 \pm .001$ & $0.023 \pm 0.01$ & $2.02 \pm 0.1$ & $0.1 \pm 0.01$ \\
$\mathrm{OB}_{8}$ & $0.003 \pm .001$ & $0.019 \pm 0.01$ & $1.22 \pm 0.2$ & $0.1 \pm 0.01$ \\
\hline
\end{tabular}

Relationship between SQMI and soil properties

Soil quality morphological index had significant correlation with clay $(\mathrm{r}=0.65 ; \mathrm{p}=0.01$; $\mathrm{n}=72)$, bulk density ( $\mathrm{r}=-0.71 ; \mathrm{p}=0.05 ; \mathrm{n}=72)$, $\operatorname{ECEC}(r=0.55 ; \mathrm{p}=0.05 ; \mathrm{n}=72)$, Bsat $(\mathrm{r}=0.42 ; \mathrm{p}=0.05$; $\mathrm{n}=72)$, Alsat $(\mathrm{r}=-0.53 ; \mathrm{p}=0.05 ; \mathrm{n}=72), \mathrm{pH}(\mathrm{r}=0.58$; $\mathrm{p}=0.01, \mathrm{n}=72)$ and $\mathrm{OM}(\mathrm{r}=0.82 ; \mathrm{p}=0.001 ; \mathrm{n}=72)$ as shown in Table 9.

TABLE 9: Correlation coefficients between SQMI and selected soil properties $(n=72)$

\begin{tabular}{|c|c|c|}
\hline Soil property & Correlation coefficient( $(r)$ & Level of significance \\
\hline Sandy & -0.26 & NS \\
\hline Silt & 0.31 & NS \\
\hline Clay & 0.65 & $* *$ \\
\hline $\mathrm{BD}$ & -0.71 & $*$ \\
\hline ECEC & 0.55 & $*$ \\
\hline Bsat & 0.42 & $*$ \\
\hline Alsat & -0.53 & $*$ \\
\hline $\mathrm{pH}$ & 0.58 & $* *$ \\
\hline $\mathrm{OM}$ & 0.82 & $* * *$ \\
\hline
\end{tabular}


These results indicate the role of organic matter, clay and $\mathrm{pH}$ in determining the quality of tropical soils. High positive significant correlation between SQMI and OM stresses the relevance of the latter in improving soil structure (47). Earlier, Scharpenseel and Miehlich (48) noted that OM relates to all forms of soil fertilityphysical, chemical and biological. In soils of open dump sites, high SQMI and OM values were recorded and in these soils were the highest concentrations of heavy metals, suggesting possible complexation of these biotoxic metals by OM.
Table 10 shows different combinations of independent variables in SQMI modelling. Predictors in SQMI ${ }_{(\mathrm{c})}$, namely ECEC, OM and sand gave the best relationship with minimal coefficient of alienation (1$\mathrm{r}^{2}$ ) value of 0.22 , followed by predictors in SQMI ${ }_{(\mathrm{f})}$ and $\mathrm{SQMI}_{(\mathrm{a})}$ combinations with OM gave good predictions. These results further confirm the role of organic matter in tropical soil fertility and quality. Good relationships in SQMI is indicative of the role of physical properties in soil quality determination while the highest prediction in SQMI reveals possibility of best soil qualities being achieved by considering both physical and chemical factors in the modelling.

TABLE 10: Regression models of SQMI and soil properties $(n=72)$

\begin{tabular}{|c|c|c|}
\hline Dependent variable & Model & $\mathbf{r}^{2}$ \\
\hline $\operatorname{SQMI}_{(\mathrm{a})}$ & $Y=30.09+0.26($ clay $)-0.43($ sand $)+4.21($ silt $)-0.21(B D)$ & $0.58^{* *}$ \\
\hline $\mathrm{SQMI}_{(\mathrm{b})}$ & $\mathrm{Y}=1.69+0.45(\mathrm{ECEC})+2.1($ Bsat $)-0.89+1.24(\mathrm{pH})$ & $0.55^{*}$ \\
\hline $\mathrm{SQMI}_{(\mathrm{c})}$ & $\mathrm{Y}=3.68+1.26(\mathrm{ECEC})+2.88(\mathrm{OM})-0.38($ sand $)$ & $0.78^{* *}$ \\
\hline $\mathrm{SQMI}^{(\mathrm{d})}$ & $\mathrm{Y}=0.99+0.28(\mathrm{pH})-4.25$ (Alsat) & $0.16^{\mathrm{NS}}$ \\
\hline $\operatorname{SQMI}_{(\mathrm{e})}$ & $\mathrm{Y}=29.25+1.22($ clay $)-3.21(\mathrm{OM})+0.82(\mathrm{ECEC})$ & $0.46^{*}$ \\
\hline $\mathrm{SQMI}_{(\mathrm{f})}$ & $Y=1.45+1.31($ sand $)-1.11($ silt $)+0.22($ clay $)+6.2(\mathrm{OM})$ & $0.62^{* *}$ \\
\hline $\operatorname{SQMI}_{(\mathrm{g})}$ & $\mathrm{Y}=0.96-0.26($ silt $)+2.26(\mathrm{CLAY})+0.33(\mathrm{OM})$ & $0.56^{* *}$ \\
\hline $\mathrm{SQMI}_{(\mathrm{h})}$ & $\mathrm{Y}=1.77+1.24(\mathrm{sand})+1.31(\mathrm{BD})-0.23(\mathrm{pH})$ & $0.21^{\mathrm{NS}}$ \\
\hline
\end{tabular}

$* *=$ significant at $\mathrm{p}=0.01, *=$ significant at $\mathrm{p}=0.05 \mathrm{NS}=$ not significant.

\section{Relationship between SQMI and heavy metals}

Tables 11 and 12 represent relationships between SQMI and heavy metals. There were significant positive correlations between SQMI and copper $(\mathrm{r}=0.42 ; \mathrm{p}=0.05 ; \mathrm{n}=72)$ and cadmium $(r=0.61 ; p=0.05 ; n=72)$.

TABLE 11: Correlation coefficients between SQMI and selected heavy metals $(n=30)$

\begin{tabular}{|l|l|l|}
\hline Heavy metal & Correlation coefficient (r) & Level of significance \\
\hline Nickel & -0.32 & NS \\
Vanadium & -0.28 & NS \\
Copper & 0.42 & $*$ \\
Cadmium & 0.61 & $*$ \\
\hline
\end{tabular}

$*=$ Significant at $\mathrm{p}=0.05, \mathrm{NS}=$ not significant. 
TABLE 12: regression models of SQMI and heavy metals $(n=30)$

\begin{tabular}{|l|c|c|}
\hline $\begin{array}{l}\text { Dependent } \\
\text { variable }\end{array}$ & Model & $\mathbf{r}^{2}$ \\
\hline $\operatorname{SQMI}_{(1)}$ & $\mathrm{Y}=0.45+0.26$ (copper) & 0.17 \\
$\operatorname{SQMI}_{(2)}$ & $\mathrm{Y}=2.23-0.30$ (cadmium) & 0.37 \\
$\operatorname{SQMI}_{3}$ & $\mathrm{Y}=1.16+7.28$ (copper)-1.71 (cadmium) & 0.41 \\
$\operatorname{SQMI}_{(4)}$ & $\mathrm{Y}=1.03-1.14($ Nickel)+2.18(vanadium) & \\
& -6.21 (copper)-0.13 (c0.13(cadmium) & 0.26 \\
\hline
\end{tabular}

\section{Conclusion}

Soils of the study site varied in quality with least soil quality being recorded on the ranch $\left(\mathrm{OB}_{3}\right)$. Soil OM had tremendous impact on the soil quality although other soil properties especially clay, $\mathrm{pH}$ and bulk density contributed. Heavy metals were present in all sampled points but in greater proportion in dump sites. Soils with the best SQMI had the highest level of heavy metals concentration. Copper and cadmium increased with rise in SQMI values while the reverse was the case in Nickel and Vanadium.

\section{References}

1. Karlen DL, Mausbach MJ, Doran JW, Cline RG, Harris RF, Schuman GE. Soil quality: A Concept, and framework for evaluation. Soil Sci Soc Am J 1997; 61:4-10.

2. FAO. FAO Yearbook Rome, Italy: 1992.

3. Oldeman LR, Vanlynden VWP, Pulles JHM. The extent of human-induced soil degradation. Wagenagen, The Netherlands: International Soil Reference and Information Centre; 1990.

4. Piovanelli C, Ceccherini MT, Castaldini M, Pagliai M, Miclaus N. Tillage impact on soil quality: Biological properties in surface soil. Halian J Agronomy 1998; 2(1):21-27.

5. Pagliai MS, Rouseva N, Vignozzi C, Piovanelli S, Pellegrini Miclaus N. Tillage impact on soil quality: Soil porosity and related physical properties. Halian J Afronomy 1998; 2(1):11-20.
6. Rayar AJ. Decline in fertility of a semi-arid savanna soil after continuous cropping. Journal of Arid Agriculture 1988; 1(2):227-241.

7. Asadu CLA, Ike O, Ugwoke BO. Cattle grazing and environment in Eastern Nigeria: Impact on soil physical properties. Outlook on Agriculture 1999; 28:103-107.

8. Bakare AA, Mosuro AA, Ossian O. Acute and genetic toxicity of leachate from three waste dumping sites in S. W. Nigeria. Book of Abstracts. National Conference on Population. Environment and Sustainable Development. Nigeria: University of Ado Ekiti (UNAD); 2002.

9. Moore PAJr, Daniel TC, Gilmour JT, Shreve BR, Edwards DR, Wood BH. Decreasing metal runoff from poultry litter with aluminium sulfate. J Environ Qual 1998; 27:92-99.

10. Senesi GS, Baldassarre G, Senesi N, Radina B. Trace element inputs into soils by anthropogenic activities and implications for human health. Chemosphere 1999; 39:343377.

11. Basta NT, McGowen SL. Evaluation of chemical immobilization treatments for reducing heavy metal transport in a smelter-contaminated soil. Environ Pollution 2004; 127:73-82.

12. Yusuf AA, Arowolo TA, Bamgbose O. Cadmium, copper and nickel levels in vegetables from industrial and residential areas of Lagos City, Nigeria. Food and Chemical Toxicology 2003; 41:375-378. 
13. Ellis DR, Salt DE. Plants, selenium and human health. Current Opinion in Plant Biology 2003; 6:273-279.

14. Zinck A. Soil survey: Epistemology of a vital discipline. ITC Journal 1990; 4:335-350.

15. FAO. World agricultute: Towards 2015/2030. An FAO perspective. Rome: FAO-Earthscan; 2003. 432 p.

16. George H, Nachtergaels FO. Global land use databases. In: Tateishi R, Hastings D. (eds.). Global Environmental databases-Present situation future directions ISPRS. Geocarto International 2002; 2:55-67.

17. Andrews SS, Karlen DL, Cambardella CA. The soil management assessment framework: A quantitative soil quality evaluation method. Soil Sci Soc Am J 2004; 68:1945-1962.

18. Foy JK. Soil organic matter changes as a function of stocking rate and grazing system under different climate regimes for the Central Plains Experimental Range. M.Sc. Thesis ( Department of Rangeland Ecosystem Science) - Colorado State University, Ft Collins, Co. 1993.

19. Pierson FB, Carlson DH, Spaeth KE. Aprocessbased hydrology submodel dynamically linked to the plant component of the simulation of production and utilization on rangelands. Spur model. Ecological Modelling 2001; 141:242260.

20. Carlson DH, Thurow TL. SPUR-91: Workbook and user guide. Publication MP-1743. Texas A \& M University, Department of Rangeland Ecology and Management in cooperation with USDA Soil Conservation Service, College Station, TX 1992.

21. Hanson JD, Shaffer MJ, Ahuja LR. Simulating rangeland production and carbon Sequestration. In: R. F. Follet, J. M. Kimble, and R. Lal (eds). The potential of U. S. Grazing lands to sequester carbon and mitigate the greenhouse effect. Boca Raton: Lewis Publishers; 2001. p. 345-370.

22. Foy JK, Teagne WR, Hanson JD. Evaluation of the upgraded SPUR model (SPUR2.4). Ecological Modelling 1999; 118:149-165.
23. Teague WR, Foy JK. Validation of SPUR 2.4 rangeland model using a cow-calf field experiment. Agriculture Systems 2002; 74:287302.

24. Acosta-Martinez, V, Zobeck TM, Allen V. Soil microbial, chemical and physical properties in continuous and integrated crop-livestock systems. Soil Sci Soc Am 2004; 68:1875-1884.

25. Thornton PK, Herrero M. Integrated croplivestock simulation models for scenario analysis and impact assessment. Agricultural Systems 2001; 70(2-3):581-602.

26. Orajaka SO. Geology. In: GEK. Ofomata (ed.). Nigeria in maps: Eastern states. Benin Nigeria: Ethiope Publishing House; 1975. p. 5-7.

27. Ofomata GEK. Soil erosion in Nigeria. The views of a geomorphologist. Inaugurate Lecture series No. 7; Nsukka, Nigeria: University of Nigeria; 1987. p. 3-33.

28. Seybold CA, Grossman RB, Hoper H, Muckel G, Karlen DL. Soil quality morphological index measured in the 1996 NRI Pilot Study. Soil Survey Horizons 2004; 45(3): 86-95.

29. Grossman RB, Harms DS, Seybold CA, Sucik MT. A morphological index for soil quality evaluation of near-surface mineral horizons. In: D. E. Stoft, R. H. Mohtar and G. C. Stainhard (eds). Sustaining the global farm. Selected papers from the $10^{\text {th }}$ International Soil Conservation Organization Meeting, Purdue University and the USDA-ARS National Soil Erosion Research Laboratory, 24-29 May 1999. Purdue University West Lafayette. 2001. p. $637-640$.

30. Gee GW, Bauder JW. Particle size analysis. In: A. klute (ed). Methods of soil analysis. Part 1. Madison, WI: American Society of Agronomy; 1986. p. $91-100$.

31. Balake HR, Hartge KH. Bulk density. In: A. Klute (ed). Methods of soil analysis. Part 1. Agro. Monogr. No. 9. ASA and SSSA, Madison WI. 1986. p. 363-375.

32. Thomas GW. Exchangeable cations. In: A. L. Page, R. H. Miller, and D. R. Keeney (eds). Methods of soil analysis. part 2., Madison, WI.: American Society of Agronomy; 1982. p. 159165. 
33. Hendershot WH, Lalande H, Duquette M. Soil reaction and exchangeable acidity. In: M. R. Carter (ed.). Soil sampling and methods of analysis Canadian Society of Soil Science. London: Lewis Publishers; 1993. p. 141-145.

34. Nelson DW, Sommers LE. Total carbon, organic carbon and organic matter. In: A. L. Page, R. H. Miller and D. R. Keeney (eds). Methods of soil analysis, part 2. Madison, WI.: America Society of Agronomy; 1982. p. 539-579.

35. Hesser GF. Textbook of soil analysis. New Jersey: John Murra Limited; 1977. p. 126148.

36. Alegria A, Barbera R, R, Boluda R, Errecalde F, Farre R, Lagarda MJ. Environmental cadmium, lead and nickel contamination: Possible relationship between soil and vegetable content. Frasenius Journal of Analytical Chemistry 1991; 339:654-657.

37. Little RC, Milliken GA, Stroup WW, Wolfinger RC. SAS system for mixed models. Cary, North Carolina, USA: Statistical system Inc; 1996. $633 \mathrm{p}$.

38. Aweto, A. O. Variability in upper soils developed on sandstones in southwestern Nigeria. The Nigeria Geographical J 1982; 25:27-37.

39. Benito E, Diaz-Fierros F. Effects of cropping on the structural stability of soils rich in organic matter. Soil Tillage Res 1992; 23:153-161.

40. Six J, Elliot ET, Paustian K. Soil structure and soil organic matter. 11. A normalized stability index and the effect of mineralogy. Soil Science Society of America Journal 2000; 64:1042-1049.

41. Ojanuga AG, Lekwa G, Okusami TA. Distribution, classification and potentials of wetland soils of Nigeria. 1996. [Monograph No. 2]- Soil Science Society of Nigeria.

42. Osuji LC, Onojake CM. The Ebocha-soil spillage 11. Fate of associated heavy metals in six months after. Ateam-Ragee 2004; 9:78-87.
43. FEPA. Guidelines and standard for industrial effluents, gaseous emissions and hazardous wastes management in Nigeria. Abuja: Federal Ministry of Environment Nigeria; 1991.

44. Lee TM. The effects of chemical remediation methods on heavy metals concentration of soil solution and their uptake by wheat in contaminated soils. MSc. [Thesis] Institute of Agricultural Chemistry, National Taiwan University 1999.

45. Liu CL, Wang YP, Liao YL, Wu CR, Huang CH, Sung CC, et al. The studies of heavy metals in soils and rice in Central Taiwan Proceedings of Soils and fertilizer Experiment Reports of 1997. Department of Agriculture and Forestry. Taiwan Provincial Government, ROC: Chung-HsingHsin-Chung, Nantow Taiwan, ROC; 1998 p. 328397.

46.Wang YP, Liao CH. The uptake of heavy metals by crop. In: The establishment of monitoring database of heavy metals in the crop. Wufeng, Taichung, Taiwan, ROC: Taiwan Agricultural Chemical and Toxic Substance Research Institute; 1999. p. 57-60.

47. Zaher H, Caron J, Ouaki B. Modelling aggregate internal pressure evolution following immersion to qualitify mechanisms of structural stability. Soil Sci Soc Am J 2005; 69:1-12.

48. Scharpenseel HW, Miehlich G. Soil fertility and organic fractions. Proceedings of Soil Management and Smallholder Development in the Pacific Islands. N. 8. Bangkok, Thailand: IBSRAM; 1989. p. 111-119.

Recebido em / Received: February 6, 2006. Aceito em / Accepted: March 23, 2006. 